\title{
Mothers Parenting Pattern to Her Son in Minangkabau Legend Malin Kundang: A Sociological Study
}

\author{
Harris Effendi Thahar \\ Fakultas Bahasa dan Seni \\ Universitas Negeri Padang \\ Padang, Indonesia \\ harrispadang@fbs.unp.ac.id
}

\begin{abstract}
This study aims to describe and interpret the form of mothers parenting pattern to her son in Minangkabau legend, Malin Kundang. The data resource of this research is Malin Kundang legend who lives in the Minangkabau cultural area, not only the one transcribed into a book (kaba), but also that in the form of an oral story that tells the success of a boy to be a successful man raised by his mother without the assistance of his father. The approach used in this research is the sociological approach. This approach assumes that legend as oral literature derived from folklore and society. Therefore, legend is a representation of the social situation of society itself at the time. The results showed that mother's parenting pattern in Malin Kundang legend is learning by experience.
\end{abstract}

\section{Keywords-Mothers Parenting Pattern, Minangkabau Legend, Malin Kundang}

\section{INTRODUCTION}

In recent years, the issue of entrepreneurship education began to be encouraged again by the government. It means, the unemployment rate in Indonesia which is in line with the lack of availability of employment is still high. The high interest to become civil worker abroad is one indicator of how our government has not succeeded in creating jobs for the young generation that grew rapidly in line with population growth.

Regarding to the phenomena stated above, the government is intensivying the revitalizing of vocational education, encouraging entrepreneurship students and opening employment opportunities by utilizing the experience of entrepreneurs as a source of inspiration (Kompas, 16/3/17, page 11). It is certainly not something as easy as we think as an entrepreneur also needs talent and mental readiness. Meanwhile, entrepreneurial talent among educated citizens is still below of our expectation, except talented as an employee / worker. College graduates looking for jobs as civil servants, private employees, even to be a member of the parliament or a politician as a new job that is considered as prestigious goal. Most college graduates are job seekers instead of job creators..

There was a tradition of Minangkabau society (West Sumatera) in the past which is very efficacious to reduce unemployment of the young generation in their homeland that is doing wander. Merantau (wandering) means going to another city that is considered to have a good economical prospect. The nomads will not go home if they have not succeeded yet in becoming a successful entrepreneur or at least a successful employee of a company or agency.

How does a young immigrant from the Minangkabau old generation learn in the past and get a job in the rantau to become a successful man? Stories of struggle and success in the overseas were much told in the legends in Minangkabau society. For example, in the legend of Malin Kundang is told a mother who lives widowed with a young son named Malin Kundang on the beach near the port of Airmanis-Padang which is often visited by ships from various countries.

Little Malin Kundang always smeared by her widowed mother about distant lands that are full with beauty and luxury. Finally, in his teenage years Malin Kundang went abroad, aboard a ship leaving his mother and promising to return home if he had become a successful person. It is true, he returned home after successfully becoming a skipper of a ship and bringing a beautiful wife, a noble woman from a foreign land. Unfortunately, this legend story ends tragically in which Malin Kundang finally becames a stone after his mother cursed him as a disobedient son.

A scientific article about the culture of wandering in the Minangkabau classic story (kaba) has also been researched by Abdurahman (2015) entitled, "Character Building with Cultural Values of Merantau: A Reflection of Classical Minangkabau Stories". According to him, the character development of a Minangkabau teenage boy is so clearly seen in Kaba "Sibuyuang Karuik" who went abroad. The personality of the main character, who behave honestly, independently, helpers and do good to others, is the characters that he got in the process of searching his identity during wandering.

The legends of Malin Deman, Cindua Mato, Rancak in Labuah, and Magek Manandin, are characters of the Minangkabau legend who were raised by widowed mothers. These legend stories usually end up happy ending or vice versa. However, an interesting thing to investigate is the widowed mothers in these legends managed to raise their children to adulthood, even to become a successful person. 
In a patriarchal culture, the care of a child is entirely the responsibility of his father. However, in the matrilineal culture of Minangkabau the care of a boy is the responsibility of his mamak (maternal uncle). In the legends of the Minangkabau, it does not always tell the role of the mamak, but much of the story is told of stories of boys raised by single parents: widowed mothers.

In general, all tribes who inhabit the archipelago of Nusantara which is now transformed into the Unitary Republic of Indonesia have folklore from the past that comes from the legend. The stories are still living in the community of supporters where the legend originated. Similar to Minangkabau ethnic community living in the province of West Sumatra and surrounding areas many legends still alive. Among of them are "Malin Kundang", "Anggun nan Tungga", "Magek Jabang"and "Batu Manangih". Likewise, in West Java, where the Sundanese tribe live, some legends that still exist are like the legend of "Tangkuban Perahu", the legend of "Prabu Siliwangi" and others.

Most of the folklore that comes from these legends has been imposed in the form of publishing books, and even some have been filmed. Special story of legend in Minangkabau cultural area that has been published in the form of a book of stories that in Minang language is called: kaba, for example kaba Malin Kundang, kaba Anggun nan Tungga Magek Jabang as examples. However, there are still many living legends that have not been imposed and still exist in the community.

In general, legend tells the story of a person's life since childhood mothered up later attributed to an extraordinary occurrence in a place that his supporters believe actually happened (Danandjaja, 1986: 66). According to the members of society, the legendary figures are always a byword as a glass of appeal in the context of family education. For example, if a child starts stubbornly to his or her parents, the child will be reminded, "Do youn want to be Malin Kundang, a lawless child?" In another hand, if a child becomes a crybaby, the child will be reminded his parents, "Malin Kundang as old as you know had gone wandering and then go home as a ship owner."

Especially about the legend of Malin Kundang has been more popular because his lawless, which is embarrassed to admit his own mother in front of his wife who is noble and rich. Caused by embarrassed, Malin Kundang, in various versions is told to push his mother to bounce to the ground from his longing hug. It caused his elderly mother to be injured and swear at her until she became a stone. On the contrary, it is not told explicitly how Malin Kundang succeeded in becoming a successful person in the city. Though his investmen is only a kind of determination. Malin Kundang only provided his mother seven packs of rice for the voyage. Although not told clearly the process of "being" him, Malin Kundang must have human capital that had been invested by his mother, the only person who nurtured and raised him into adolescence.

Through positive thinking about the length of life of these legends, of course these legends contain valuable values to be examined. That is, the success of the legendary characters becomes mature and the "person" was totally contributed by the care of his mother, even without a father. Indeed, within the matrilineal Minangkabau culture of the past, a boy does not need the care of a father because his father was prioritizing his role as a mamak (uncle) to his sister's sons. Minangkabau boy after able bathing himself must sleep in a surau and come home after the morning to his mother's house. In surau, boys learn to study and bersilat (self-defense art of Minangkabau), while at home he cared by his mother.

How does the Minangkabau legend represent the pattern of the boy's upbringing to become a mature, character, and successful man (paguno) without formal education? It is assumed, the educational concept used by Engku Syafei in INS Kayu Tanam past was like the pattern of mother's care in Minangkabau legends which is now known as the concept of education by doing by learning and learning by experience. In relation to that, this research becomes important if it turns out the mother's parenting pattern in Minangkabau legend as a representation of social reality of Minangkabau society in the past, particularly in relation to create a concept of effective character education for the young generation in accelerating the equitable development of the nation.

The role of the mother according to Minangkabau culture is very central. Mother is also called as bundo kanduang (biological mother) who gave birth to a child from his womb. According to custom, bundo kanduang is limpapeh rumah gadang, or the main pole of the traditional house building. Mother is a woman who is entitled to hold the power of economic resources such as rice fields and farm. According Rajo Penghulu (2004: 71-95), in addition to the holder of the power of economic resources women have voting rights in musyawarah. Mothers play a greater role to educate their children because her husband is more role as a mamak in the family of his mother.

Legend is a folktale that is an oral literature (folktale), or commonly referred to as the folk prose story (Danandjaja, 1991: 50). As a literary work born of an anonymous author, it can not be separated from the representation of aspects of life that occur in society, because the author is a member of the community. Furthermore, the literary work born of the representation of the life of his society is the self-image of society itself (Ratna, 2004: 332-333). Moreover, literary work is not the reality of life itself but rather an aesthetic imaginative reality resulting from the representation of a reapity that must be understood through an approach as a bridge of interpretation of the meaning of a study. Accordingly, this study uses a sociological approach; in accordance with the philosophical basis of sociological approach is the existence of an intrinsic relationship between literary works with society (Ratna, 2004: 60).

The legend figures who live in Minangkabau in general are men who were raised by widowed mothers. Allegedly, in a legend in Minangkabau that does not tell explicitly about the existence of the father of story characters closely related to the matrilineal family system, though that needs to be proved by a study as well. In general, the characters in these legends were raised by a single parent family, namely his mother. Not only the character of Malin Kundang, Cindua Mato figures were never 
told about his father's presence, except from the story of his birth which stated that his mother was pregnant for drinking the remaining coconut water from Bundo Kanduang ivory.

Minangkabau legend figures that become interesting when associated with the role of his mother who is a successful single parent became caregivers of his children become adults and become "people". Thus, the focus of this research is the pattern of mother care that is represented from the legend of Minangkabau Malin Kundang legend which is considered indispensable for the glass of appeal for the world of education, especially the pattern of child care in the present day in order to prepare the younger generation character and tough.

Based on the focus of the above problem, this research problem can be formulated in the form of the following questions. (1) How is the representation of mother's parenting pattern in Minangkabau legend Malin Kundang through sociological approach? (2) What are the factors affecting mother's parenting in Minangkabau Malin Kundang legends through a sociological approach?

\section{METHOD}

The source of data is the legend of Malin Kundang who has been posted and who circulated verbally in the community. The data were collected by recording parts of the legend related to Malin Kundang's childhood with his mother interpreted as part of his mother's parenting with content analysis techniques. Interpretation of data is discussed through the literary sociology approach.

\section{FINDING AND DISCUSSION}

Malin Kundang legend has been written by many people, both by using Minangkabau language, Indonesia, and foreign languages. One of them is Malin Kundang written in two languages (Indonesian-English) by M Rantiss published by Bintang Indonesia (2013). Prior to this, Malin Kundang has also been published by Obor Foundation and written by Uddin Syamsudin (1980). Although Malin Kundang is a legend from Minangkabau cultural area in West Sumatra, but has become a popular legend in the archipelago. Therefore, the legend of Malin Kundang is now generally written in Indonesian language.

The legend of Malin Kundang now serves as a bedtime story for children because of its educational factor, i.e. do not imitate Malin Kundang who is lawless to his mother, will later become a stone. It is so rarely books of Malin Kundang legend that tells explicitlyabout period of his childhood when mother cared for, except in passing. Nevertheless, there are some important findings from within oral and written text, such as the following.

(1) There are three versions of Malin Kundang's father, first, dying of illness; second, lost in the storms at sea; and third, never to return from a faraway voyage.

(2) There are two versions of the age of Malin Kundang when his father left. First, when he was still in his mother's arms. Since the loss of his father, Malin Kundang is carried everywhere by his mother so that the people around the year exactly when Malin Kundanglah who was carried by his mother. Secondly, Malin Kundang was in his early years when his father did not come back. Malin goes wherever his mother goes, including going to search for firewood for cooking food. At that time, Malin Kundang is well known as a diligent and obedient child.

(3) According to some versions, Malin Kundang's childhood is a diligent child helping his poor mother. Every day, morning and evening Malin Kundang sells cakes at Sweet Water Beach harbor. It was very helpful to her mother because Malin Kundang was good at trading so her cake was always exhausted, even though she was forced to come home late at dusk. Narrated, other than Malin Kundang famous as a diligent child, he is also known as an honest child. Therefore, the people of the coastal community where he lives put affection on him.

These three important notes can lead to this research exploring how Malin Kundang relates to his mother who is his true caregiver. Meanwhile, the story of the legend's climax that causes Malin Kundang to be called a rebellious child is when he lies to his beautiful wife, rich, and arrogant, that who embraced her and confessed her mother was not her mother. Again he lied, telling his wife that his mother had died. This climax section is already very popular and this section is also the core of the legend as a lesson.

From some of the findings stated above, it is seen how little-Malin Kundang is cared for lovingly by his mother. It is in accordance with the role of mother (bundo kanduang) in Minangkabau culture, educating children more than a father because his father plays more role in the home of his parents as mamak (Rajo Penghulu, 2004: 71-95). Hard work helps her mother to continue living for daily wood fire, so that Malin Kundang trained physically and mentally from childhood, understanding the meaning of life that life must strive for.

We can state from the findings, Malin Kundang received special attention by the ship's captain for his craft and skill as a porter of loading and unloading. Therefore, Malin was invited to sail by the skipper. This is something that is very exciting because it is secretly Malin Kundang harbor the desire to go sailing to countries far away as his mother's stories. Furthermore, the success of Malin Kundang to get a beautiful wife again nobleman and became the owner of the ship is not told in detail, either through oral stories or through books that have been published.

Malin Kundang success to become the owner of the ship proved by sailing and anchored in his hometown on the coast of Air Manis, Padang. Its success has caused people to wonder about the harbor because they are very familiar with Malin Kundang. This remarkable success made the people immediately tell their mothers that Malin Kundang has returned home with all the 
luxury. The statement of the villagers is also a tribute to the mother of Malin Kundang who has managed to nurture and educate their children. Unfortunately, Malin Kundang embarrassed to admit his mother who has been old and poor to his wife.

The final part of Malin Kundang legend that causes him to be cursed by his mother to stone is a part of her mother's negligence in educating ethics and morals. Apparently, her mother's parenting is only from the material poverty background not including moral poverty.

\section{CONCLUSION}

From the findings and discussion, it can be concluded several things: (1) The pattern of mother's care Malin Kundang represented in the form of persuading his son in everyday activities such as gathering firewood to train to become skilled and diligent work and understand the meaning of life. Next teach Malin Kundang trade by selling cakes every day to understand the importance of raising money in life. Thus, the mother of Malin Kundang apply parenting to his son by giving him experience by doing alone or learning by doing it, learning by doing which then becomes learning by experience. (2) The pattern of care adopted by Malin Kundang's mother departs from the state of his single limbs (poor parent). Therefore, the factors influencing the parenting of Malin Kundang mother are economic factors and cultural factors of Minangkabau which put the function of woman (bundo kanduang) as the holder of household economic control.

\section{References}

Asmarandana, T. (2014). Legenda Malin Kundang si Anak Durhaka. Surabaya: Duta Ilmu

Abdurahman. (2015).'Pembangunan Karakter dengan Budaya Merantau: Sebuah Refleksi Cerita Klasik Minangkabau", Prosiding Seminar Nasional Bahasa, Sastra, dan Perpustakaan. Padang:Jurusan Bahasa dan Sastra Indonesia dan Daerah, FBS UNP.

Dananjaya, J. (1991). Folklore Indonesia, Ilmu Gosip, Dongeng, dll. Jakarta: Grafiti

Hakimy, I. (2004). Pegangan Penghulu, Bundo Kanduang, dan Pidato Alua Pasambahan Adat di Minangkabau. Bandung: PT Rosda Karya.

Rantis, M. (2013). Malin Kundang. Jakarta: Bintang Indonesia.

Ratna, N. K. (2004). Penelitian Sastra.Yogyakarta: Pustaka Pelajar.

Udin, S. (1996). Malin Kundang. Jakarta: Buku Obor 